\title{
HISTORICITY OF THE RESURRECTION: A THEOLOGICAL APPROACH OF EVIDENCE OF THE RESURRECTION OF CHRIST IN THE NEW TESTAMENT
}

\author{
Made Astika \\ sttjaffraymakassar@yahoo.co.id \\ astikadek@yahoo.com
}

\section{INTRODUCTION}

There are some who question the validity of the crucifixion and resurrection of Jesus Christ. If Jesus Christ was not murdered and did not rise from the grave, then He is no different than any of the wise men or prophets of other religions. Jesus' resurrection is what gives Him the authority to say He is God and that there is no other means to experience eternal salvation except to acknowledge Him as Lord and Savior.

On the long journey of the church history, there are many of objections emerge related to the resurrection of Christ. The enemies of Christianity tried to break the truth of the resurrection of Christ.

On the other hand, there are not few of Christians hesitate the resurrection of Christ as the event in the history of human being. Theologians' views of resurrection influence Christian faith. Many of theologians were raised up false view of resurrection. Their view brought many Christians fall into doubt.

Based on these realities, this research paper emerged as a burden and responsibility to reveal the biblical concept about resurrection of Christ and its application in Christian life. This effort is poured out on theme: "Historicity of Resurrection: A Theological Approach of Evidence of the Resurrection of Christ in the New Testament." Hopely this paper will coloring and encouraging the believer to stand on the truth of resurrection because the resurrection is the foundation of Christian faith for salvation. 


\section{CHAPTER I THE IMPORTANCE OF RESURRECTION}

Many people do not believe in the resurrection. Even in New Testament times we find those who refused to believe in the resurrection. The Sadducees were materialists who did not believe in resurrection as the Pharisees did. Even in the church, some people did not believe in the resurrection. St. Paul wrote concerning this in 1 Corinthians 15. In 2 Timothy 2:17-18, it seems that Hymenaeus and Philetus were mentioned by Paul as people who did not really believe in the resurrection of the body. ${ }^{1}$

The reality of resurrection of Christ was clearly mentioned in the fourth Gospels and the doctrine about Christ's resurrection was clearly explained by the apostle of Paul on his letter to the Corinthians. The apostle Paul explain of how important the resurrection of Christ for the faith of the believers.

\section{A. Foundation of Christian Faith}

The resurrection of Jesus Christ is the very heart of Christianity, and without the resurrection, there is no Christianity. The apostle Paul clearly says, "If Christ has not been raised, our preaching is useless and so is your faith. ... We are then found to be false witnesses about God, for we have testified about God that he raised Christ from the dead." In that same chapter he says "If Christ has not been raised, your faith is futile; you are still in your sins. Then those also who have fallen sleep in Christ are lost. If only for this life we have hope in Christ, we are to be pitied more than all men." But then Paul triumphantly declares, "But Christ has indeed been raised from the dead, the firstfruits of those who have fallen asleep" (1 Corinthians 15:14-24).

The resurrection of Christ is essential to the validity of the Christian faith. Apart from the resurrection, the believer's faith and the preaching of the gospel are vain; those who proclaim the resurrection are liars, and there is no hope for the future resurrection if Christ was not raised. ${ }^{2}$ Further more, Thiessen explain that Christ's physical resurrection is vitally important, is evident from the fundamental connection of this doctrine with Christianity. In l Corinthians 15:12-19, Paul shows that everything stands or falls with Christ's bodily

\footnotetext{
${ }^{\text {l }}$ P. G. Mathew, The Resurrection of Jesus Christ, available from http://dcn.davis.ca.us/ gvcc/radio_trans/resurrection.html, cited on April $8^{\text {th }} 2009$

${ }^{2}$ Robert P. Lightner, Handbook of Evangelical Theology (Grand Rapids, Michigan: Kregel Publications, 1995), 89.
} 
resurrection. ${ }^{3}$ Wiersbe clearly tells, "If He was not raised, there is no Gospel to preach, if there is no Gospel, then you have believed in vain and you are still in your sins! If there is no resurrection, believers who have died have no hope. The resurrection is not just important; it is "of first importance," because that all we believed hinges on it. ${ }^{4}$

\section{B. The Fulfillment of the Prophecy}

The resurrection of Jesus Christ was foretold in the Old Testament as well as by the Lord Jesus Himself in the New Testament. In the Gospels, the Lord Jesus repeatedly spoke to His disciples of His death and resurrection before it took place.

This section is composed mainly of verses which confirm that Christ's resurrection happened not by chance, but according to God's predetermined plan. In the entire Bible, and especially in the New Testament, Christ's resurrection was repeatedly foretold.

Jesus pointed to the experience of Jonah, "For as Jonah was three days and three nights in the belly of a huge fish, so the Son of Man will be three days and three nights in the heart of the earth," recorded in Matthew 12:40. The only legitimate conclusion of this verse is that Jesus knew long in advance about His death, burial, and resurrection, and saw His life moving toward the climax; and the Christological implications must not be avoided. . Jonah was a sign to the people of Niniveh because he had experienced (in the great fish) "death," burial, and resurrection. The only sign Jesus would give to His nation was death, burial, and resurrection, 6 to answer the Jews requirement of Messianic sign.

Other prophecies of Messiah's resurrection in the Old Testament was recorded in the book of Psalm 16:8-11 (see Acts 2:25-28); 22:22 ff (Heb. 2:12); Isaiah 53:10-12; and Psalm 2:7 (See Acts 13:32-33).

In regard to resurrection Psalm 16:10 anticipated the fact that His body would not see corruption but would be resurrected. All the passages that speak about Christ's kingdom reign in the Millennium as well as His present session in heaven support the fact of His bodily resurrection.

William

${ }^{3}$ Henry C. Thiessen, Lectures in Systematic Theology (Grand Rapids, Michigan:

B. Eerdmans Publishing Company, 1987), 243.

${ }^{4}$ Warren W. Wiersbe, The Bible Exposition Commentary, Vol. 1 (Wheaton Illinois:

Victor Books, 1989), 618.

${ }^{5}$ Frank E. Gaeblin, gen. ed. The Expositor's Bible Commentary, vol. 8 (Grand Rapids, Michigan: Zondervan, 1984), 296.

${ }^{6}$ Warren W. Wiersbe, The Bible Exposition Commentary, Vol. 1 (Wheaton Illinois: Victor Books, 1989), 43.

${ }^{7}$ Lewis Sperry Chafer, Sytematic Theology, Volume one, Abridged Edition (Wheaton, Illinois: Victor Books, 1988), 230. 


\section{Approval of Christ's Divinity}

By His resurrection, Christ brought His humanity fully into the divine sonship and thus designated it as the Son of God. If Christ had not risen from the dead there would be no compelling reason to suppose that He was more that an ethical teacher or philosopher or fraud than other men. This is because Christ himself affirmed that he would rise from the dead as a final confirmation of his doctrine. ${ }^{8}$

The resurrection proves that Jesus Christ is God. That is exactly what God the Father wanted to communicate to us, as apostle Paul wrote that the Gospel he promised beforehand through his prophets in the Holy Scripture regarding his Son, who as to his human nature was a descendant of David, and who through the Spirit of holiness was declared with power to be the Son of God by his resurrection from the dead: Jesus Christ our Lord. ${ }^{9}$

The Jews crucified Jesus Christ because, to them, he was blaspheming when he said that he was the Son of God, equal to the Father. The resurrection of Jesus Christ demonstrates the truth that he is who he said he was. In the resurrection of Jesus Christ man can see the clear demonstration of the power of the true God. The resurrection would have meant that God has been ultimately revealed in Jesus. ${ }^{10}$

The resurrection of Jesus witnesses to the immense power of God Himself. To believe in the resurrection is to believe in God. If God is exists, and if He created the universe and has power over it, He has power to raise the dead also. If He does not have such power, He is not a God worthy of believers' faith and worship. Only He who created life can resurrect it after death, only He can reverse the hideousness that is death itself, and only He can remove the sting that is death and the victory that is the graves. In resurrecting Jesus from the grave, God reminds us of His absolute sovereignty over life and death.

\footnotetext{
8 Raymond Taouk, The Importance of the Resurrection, available from http://www.catholic apologetics.info/apologetics/islam/risen.htm, cited on April $7^{\text {th }}$ 2009

${ }^{9}$ Roman 1:14 New International Version

${ }^{10}$ Millard J. Erickson, Christian Theology (Grand Rapids, Michigan: Baker Academic, 1985), 699.
} 


\section{CHAPTER II \\ THE EVIDENCE OF RESURRECTION}

Beginning in the latter part of the seventeenth century, some in the church began to question putting faith in miracles, particularly in the miraculous resurrection of Jesus Christ. In England deists like John Toland refused to believe in the resurrection. Rationalists like H. S. Reimarus refused to believe in miracles, and questioned the authority of the Bible and the church. The theologian David Strauss systematically denied any miracles in his work, Life of Jesus, and in the twentieth century Karl Barth, along with Rudolf Bultmann, also denied the resurrection of the body. Today most liberal churches deny the resurrection as well as any miracle as recorded in the New Testament. ${ }^{\text {ll }}$

The resurrection of Christ is strongly supported throughout the Bible, and especially in the New Testament. First, the account of Christ's resurrection is recorded in each of the four Gospels. Furthermore, the earlier apostles and disciples, who were eyewitnesses of Christ's resurrection (Acts 1:22), took this fact as the focus of their gospel preaching (Acts 2:32; 4:33). They witnessed of the resurrected Christ not only by their teaching but also by their living, as portrayed in the Acts and the Epistles. The disciples were transformed by forty days with Jesus after His resurrection. ${ }^{12}$

\section{A. The Empty Tomb}

It was recorded in the fourth Gospels that the tomb in which Jesus Christ was placed was empty on the third day. The New Testament witnesses were fully aware of the background against which the resurrection took place.

While Jesus was alive, he had predicted that he would rise from the dead. He challenged his enemies: "Destroy this temple, and I will raise it again in three days." He was speaking about his body (John 2:1922). Jesus also told his disciples many times that he would be killed by the leaders in Jerusalem, but be raised to life on the third day. The leaders who killed Jesus were aware of this prediction that he would rise from the dead. Although they did not believe it, they wanted to ensure that it would not happen, so they set a guard around the tomb.

The Gospel tells that on the next day, the one after Preparation Day, the chief priests and the Pharisees went to Pilate. "Sir," they said, "we remember that while he was still alive, that deceiver said, "After

\footnotetext{
${ }^{11}$ P. G. Mathew, The Resurrection of Jesus Christ, available from http://dcn.davis.ca.us/-gvec/radio_trans/resurrection.html, cited on April $8^{\text {th }} 2009$

${ }^{12}$ Rick Warren, Purpose Driven Life (Grand Rapids, Michigan: Zondervan, 2002), 10.
} 
three days I will rise again.' So give the order for the tomb to be made secure until the third day. Otherwise, his disciples may come and steal the body, and tell the people that he has been raised from the dead. This last deception will be worse than the first." "Take a guard," Pilate answered. "Go, make the tomb as secure as you know how." So they went and made the tomb secure by putting a seal on the stone and posting the guard. ${ }^{13}$

A Roman guard of strictly disciplined fighting men was stationed to guard the tomb. This guard affixed on the tomb the Roman seal, which was meant to "prevent any attempt at vandalizing the sepulcher. Anyone trying to move the stone from the tomb's entrance would have broken the seal and thus incurred the wrath of Roman law. But three days later the tomb was empty. The followers of Jesus said He had risen from the dead. ${ }^{14}$

The fact of empty tomb was told by an angel to Mary Magdalene and the other Mary. There was a violent earthquake, for an angel of the Lord come down from heaven and going to the tomb, rolled back the stone and sat on it. His appearance was like lightning, and his clothes were white as snow. The guards were so afraid of him that they shook and became like dead men. The angel said to the women, "Do not be afraid, for I know that you are looking for Jesus who was crucified. He is not here; he has risen, just as he said. Come and see the place where he lay. Then go quickly and tell his disciples: 'He has risen from the dead and is going ahead of you into Galilee. There you will see him.' Now I have told you." 15

\section{B. The Witnesses of Resurrection}

The resurrection of Christ was a miracle, and the kind of evidence needed to prove this fact is the same as that which is needed to prove any other miracle. The witnesses are one of the evidence to prove it. ${ }^{16}$ On the cross, Jesus was exposed to the eyes of unbelievers; but after the resurrection, He was seen by believers who could be witnesses of His resurrection. ${ }^{17}$

The Scripture tells that it was Christ appearance to His apostle that caused them to believe in His resurrection as prior to this they all

\footnotetext{
${ }^{13}$ Matthew 27:63-66 New International Version

${ }^{14}$ Josh McDowell, Evidence for the Resurrection, available from, http://www.bible.ca/d-resurrection-evidence-Josh-McDowell.htm, cited on April $7^{\text {th }}$ 2009

${ }^{15}$ Matthew 28:2-7 New International Version

${ }^{16}$ Henry C. Thiessen, Lectures in Systematic Theology (Grand Rapids, Michigan: William

B. Eerdmans Publishing Company, 1987), 244.

${ }^{17}$ Compare with Acts 1:22; $2: 32 ; 3: 15 ; 5: 32$ ).
} 
believed him to be dead. In fact even after His resurrection the Apostle Thomas protested openly that he refused to believe unless he saw the risen Christ himself, and so Christ did appear to him in the flesh affirming to him "Because you have seen me, you have believed; blessed are those who have not seen and yet have believed" (John 20:29).

The Lord Jesus "presented Himself alive to His disciples after His suffering by many irrefutable proofs, appearing to them through a period of forty days" (Acts 1:3). The angels and the Holy Spirit also testified of His resurrection (Matthew 28:5-6; John 20:11-13; Acts 5:29-32). Follows are several proofs related to the appearance of Christ to His followers during forty days before $\mathrm{He}$ ascended to Heaven as recorded in the Bible. $^{.8}$

\section{Appearance to Mary Magdalene}

The first witnesses to see the risen Christ was Mary Magdalene after Jesus' death and resurrection. It is touching that He appeared to her after He had risen from the dead. She had found out that his body was missing and she wanted to recover it. So she had really come seeking Jesus with a heart full of love.

The gospel tells that in the early Sunday morning, Mary stood outside the sepulcher crying. She stooped down and looked into the sepulcher. A wondrous sight greeted her. Two angels dressed in white were sitting one at the head and the other at the feet where Jesus' body had lain! They asked her, "Woman, why are you crying?" She answered, "Because they've taken away my Lord and I don't know where they have laid him."

Then she turned around and saw Jesus himself standing there, but she didn't recognize Him. Jesus asked her, "Woman, are you crying? Who are you looking for?" Thinking He was the gardener, Mary replied, "Sir, if you have taken Him away, tell me where you have laid him, and I'll take Him away." Then Jesus tenderly spoke her name, "Mary." Startled and suddenly recognizing Her Lord, she turned and ecstatically responded, "Rabboni!"

Jesus responded, "Don't touch me for I haven't yet ascended to My Father, but go tell my brothers, I'm ascending to My Father, and your Father and to My God and your God."

\section{Appearance to Other Women}

It was recorded in Matthew 28:9 that Jesus revealed Himself alive to two or more other women as well. Again we notice that the second

18 Ultimate Victory of The Resurrection, available from
http://www.resurrection.azprophecy.com/ gospels-record-resurrection.php, cited on
April $7^{\text {th }} 2009$


appearance was to women whose testimony wouldn't have counted in a court of law of their day. So if this was merely a legend, why choose women as the first witnesses?

Jesus met them and said, "Rejoice!" They too saw the Lord. They came and held Him by the feet - - the wounded, bleeding feet of Jesus. He was probably bare-footed or wore sandals, so the scars on His feet would have been visible. These women worshipped Him for they knew He was their Lord. If Jesus wasn't truly God, He wouldn't have accepted their worship. The risen Savior is to be worshipped.

\section{Appearance to Peter}

In Luke 24:34 we see that the resurrectedChrist had a private meeting with Peter after Jesus' death and resurrection.

We're not told a thing about this interview. In Mark 16:7 a special mention is made of Peter because of his threefold denial of Christ. You see, Peter had miserably failed the Lord, but Jesus brought him back to Himself. The Lord went to him personally and privately and restored him. During this precious private interview, Peter confessed and was restored.

\section{The two on the way to Emmaus}

In Luke 24:13 we read of this encounter that happened on the day of the resurrection. Two followers of Christ were talking together of all the things that had happened. One of them was named Cleopas.

\section{Appearance to Ten apostles}

Jesus appeared after his resurrection to 10 of his disciples at one time. This is recorded in John 20:19. Thomas was missing on that occasion. This was the same day - resurrection day - -in the evening at the close of the day when the doors were shut. The disciples were hiding because they were afraid of what the Jewish leaders would do to them.

\section{Appearance to Thomas}

Thomas was not with the other apostles when Jesus visited them at the first time appearance. This meeting with Thomas happened on a Sunday a week after Jesus had appeared to the other 10 disciples. Thomas didn't go to all the meetings and therefore missed out. The ecstatic 10 men joyfully shared with Thomas that Jesus was risen.

\section{Third Appearance to the Apostles}

After Jesus had risen from the dead, the apostles returned to fishing. They had fished all night but caught nothing. Probably they were dependent on fish for their food. Jesus appeared to them again 
" this time standing on the shore. He commanded them to cast their net on the right side of the ship. Immediately it filled up with 153 great fishes. John said, 'It is the Lord." Then Jesus prepared breakfast for them and asked them to come and eat.

\section{Appearance to 500 believers}

1 Corinthians 15:5 was written about 20 years after the resurrection of Christ. This text states that Christ was seen of Cephas (Peter) and then the 12 and then about 500 brethren at once. Many were still alive 20 years later. You could go and ask these 500 eyewitnesses about the risen Christ whom they had seen.

\section{Appearance to James}

The Bible tells that the resurrected Christ was also seen by James (I Cor.15:7). This apparently was another personal interview. James was the head apostle in the city of Jerusalem. He was the chairman who many looked to for leadership. This disciple was convinced Jesus rose from the dead.

\section{The ascension of Christ}

Acts 1:10 recounts to us the ascension of Christ. While they looked steadfastly toward heaven, Jesus was taken up and covered by a cloud. Then two angels appeared and told the crowd that Jesus would return the same way He went into heaven.

\section{Appearance to Paul the Apostle}

Jesus showed Himself to Paul on the road to Damascus (Acts 9:3-9 and 1 Corinthians 15:8.

Another factor crucial to interpreting Christ's appearances is that He also appeared to those who were hostile or unconvinced. Saul despised Christ and persecuted Christ's followers. It was a lifeshattering experience when Christ appeared to him. Although he was at the time not a disciple, he later became the apostle Paul, one of the greatest witnesses for the truth of the resurrection.

\section{CHAPTER III THE FALSE THEORY OF RESURRECTION}

For years philosophers and others who claim to be extremely intelligent have said that Christianity is absurd and that no intelligent person could believe Jesus Christ rose from the dead. Skeptics have felt that those who believe in the resurrection of Christ are foolish and 
superstitious and that they've just swallowed a hoax, even if it is a wellmeaning hoax. ${ }^{19}$

For centuries many of the world's distinguished philosophers have assaulted Christianity as being irrational, superstitious and absurd. Many have chosen simply to ignore the central issue of the resurrection. Others have tried to explain it away through various theories. But the historical evidence just can't be discounted. ${ }^{20}$

Follows are several theories which come up and become big issues on the history of Christianity. Theories emerge to deny the truth of resurrection of Christ.

\section{A. The Stolen Body Theory}

Rarely suggested by modern biblical scholars, was popular among Roman and Jewish writers until the Middle Ages. The major premise of this theory is that Jesus tomb was empty because his followers stole the body.

This theory was emerged firstly by the chief priest and it was recorded in the Bible. Matthew tells that the guards went into the city and reported to the chief priests everything that had happened. When the chief priests had met with the elders and devised a plan, they gave the soldiers a large sum of money, telling them, "You are to say, "His disciples came during the night and stole him away while we were asleep.' If this report gets to the governor, we will satisfy him and keep you out of trouble." So the soldiers took the money and did as they were instructed. And this story has been widely circulated among the Jews to this very day. ${ }^{21}$

This is highly unlikely because; firstly, Jewish authorities requested a unit of tough Roman soldiers to guard the tomb and prevent this very thing, since Jesus had predicted his resurrection. The guards knew that if he escaped, such an offense was punishable by their death. This is documented in the Bible. If you do not believe the Bible, do you believe that the Jews would have allowed Jesus body to be stolen?

Secondly, the disciples were proponents of the highest ethical standards. Therefore, for them to have removed the body, lied about its whereabouts and then continued to practice and preach God's holy moral code and die as martyrs seems improbable. If the disciples died horrific deaths for believing in the resurrection of Jesus when they

\footnotetext{
${ }^{19}$ Evidence of the Resurrection, Available from http://www.resurrection.azprophecy.com/, cited on April $7^{\text {th }} 2009$

${ }^{20}$ Josh McDowell, Evidence for the Resurrection, available from, http://www.bible.ca/d-resurrection-evidence-Josh-McDowell.htm, cited on April $7^{\text {th }}$ 2009

${ }^{21}$ Matthew 28:11-15 New International Version
} 
actually hid his body, they were insane. If they were insane enough to die for a lie, there should be much documentation on how crazy the disciples were after Jesus death.

The body was stolen is one of the various theory to explain the empty tomb. But those theories are laughed at today by thousand serious scholars. In fact, they have been considered dead and refuted for almost a hundred years. For example, the Jews or Romans had no motive to steal the body-they wanted to suppress Christianity, not encourage it by providing it with an empty tomb. The disciples would have had no motive, either. Because of their preaching on the resurrection, they were beaten, killed, and persecuted. Why would they go through all of this for a deliberate lie? No serious scholars hold to any of these theories today. What explanation, then, do the critics offer, you may ask? Craig tells us that "they are self-confessedly without any explanation to offer. There is simply no plausible natural explanation today to account for Jesus' tomb being empty. If we deny the resurrection of Jesus, we are left with an inexplicable mystery." ${ }^{22}$

The resurrection of Jesus is not just the best explanation for the empty tomb; it is the only explanation in town.

\section{B. The Swoon Theory}

According to this theory, Jesus did not really die, but merely fainted, while it was thought that He had actually died..$^{23}$ This theory was, popularized by Venturini several centuries ago, is often quoted today. This is the swoon theory, which says that Jesus didn't die; he merely fainted from exhaustion and loss of blood. Everyone thought Him dead, but later He resuscitated and the disciples thought it to be a resurrection. ${ }^{24}$

The gospel clearly mention that Jesus already dead on the Cross. The Gospels tells that the Roman soldiers pronounced Jesus dead, and He was dead. The mixture of blood and water that poured out of the wound they made in his side is clear evidence of this.

\footnotetext{
${ }^{22}$ Desiring God Staff, Historical Evidence for the Resurrection, September 12, 2007, available from http://www.desiringgod.org/ResourceLibrary/Articles/ByDate/2007/2390_Historical_E vidence_for_the_Resurrection/, cited on April $7^{\text {th }} 2009$

${ }^{23}$ Louis Berkhof, Systematic Theology (Grand Rapids, Michigan: William B.

Eerdmans

Publishing Company, 2002), 348.

${ }^{24}$ Josh-McDowell, Evidence for the resurrection, available from http://www.bible.ca/d-resurrection-evidence-Josh-McDowell.htm, cited on April $7^{\text {th }}$ 2009
} 
William Edwards, M.D., explain that crucifixion was an excruciating experience, indeed, these two words are clearly related. The cause of death by crucifixion was multifaceted and torturous. These factors included exhaustion asphyxia, dehydration, and congestive heart failure. ${ }^{25}$ That Jesus could have survived such agony on a Roman cross, to limp out of the tomb by His own power, is improbable enough.

Crucifixion was a most painful and certain means of death. Christ was whipped by Roman soldiers before his crucifixion (Mt 27:26-31). Christopher Louis Lang explains that the Roman method for this was to give thirty-nine lashes before crucifixion (forty lashes were considered legally dead after which point an individual could no longer be punished). The effect of this was to induce considerable blood loss. The Romans used what was called a "cat-of-nine-tails." This whip had many ends to it and usually had pieces of bone, glass, and metal shards attached to it which would rip open the flesh. ${ }^{26}$ After being whipped, Jesus was forced to carry his own cross to the place of crucifixion. The gospel records indicate that in his weakened state, he was unable to carry the cross (which would have been carried on his wounded back Mt 27:32).

Jesus was then nailed to a Roman cross at which point his death came within hours. The Jews were concerned that no bodies would be left on crosses at sundown that evening because it was the beginning of the Sabbath. The Apostle John wrote, "Now it was the day of Preparation, and the next day was to be a special Sabath. Because the Jews did not want the bodies left on the crosses during the Sabath, they asked Pilate to have the legs broken and the bodies taken down." ${ }^{27}$ Crucifixion victims, depending on their health and the method of crucifixion, could last days on a cross. Victims died primarily through blood loss, dehydration, and suffocation. In order to breathe when on a cross, it is necessary for the victim to push up with their legs to release the pressure on the lungs. This is a painful process because of the nails in both the hands and feet or ankles. The purpose of breaking the victim's legs was so that they would be unable to push themselves up to breath and thus dies more quickly.

However, when they came to Jesus the Roman guards realized he was dead already. The Apostle John continues wrote, "The soldiers therefore came, and broke the legs of the first man, who had been

\footnotetext{
${ }^{25}$ Rev. Gary W. Jensen, M.Div. and Paul S. Taylor, Is it possible that Jesus did not die, but only fainted on the cross, later recovering from His wounds? Available from http://www.christiananswers.net/q-eden/edn-t013.html, cited on April $8^{\text {th }} 2009$.

${ }^{26}$ Christopher Louis Lang, Historical Evidence for the Resurrection of Christ, available from http://www.xenos.org/classes/papers/doubt.htm, cited on April $7^{\text {th }} 2009$.

${ }^{27}$ John 19:31 New International Version.
} 
crucified with Jesus, and then those of the other. But when they came to Jesus, and found that He was already dead, they did not break His legs. Instead, one of the soldiers pierced Jesus' side with a spear, bringing a sudden flow of blood and water. ${ }^{128}$ The Apostle John records this detail of piercing Jesus side to indicate that he was in fact dead.

\section{The Hallucination Theory}

Another attempted explanation claims that the appearances of Jesus after the resurrection were either illusions or hallucinations. Some claim that witnesses to Christ's resurrection must have been hallucinating or experiencing mass hysteria. The disciples projected hallucinations of Jesus after his death, from which they mistakenly inferred his resurrection. Is this possible?

The hallucination theory became popular during the nineteenth century and carried over into the first half of the twentieth century as well. It maintains that the disciples were so grieved by the loss of their teacher that they experienced visions of him and then concluded he had risen from the dead. At first this seems reasonable since they definitely were shaken by his death.

The disciples could not have been hallucinating because this theory is flatly contradicted by certain psychological principles governing the appearances of hallucinations. The disciples' was touched Jesus and gave Him food (cf. Luke 24:39-43), which cannot be done with a hallucination. In addition, this theory fails to account for the empty tomb. Unsupported by the psychological principles governing the appearances of hallucinations, this theory also does not coincide with the historical situation.

The 500 plus brethren all saw Him at the same time (1 Cor. 15:6), so it could not have been a hallucination or a deception. This event may have been just before His ascension (Matt. 28:16ff). ${ }^{29}$

This is good ground for rejecting hallucination hypothesis. It is psychologically implausible to posit such a chain of hallucinations. Hallucinations are usually associated with mental illness or drugs; but in the disciples' case the prior psycho-biological preparation appears to be wanting. The disciples had no anticipation of seeing Jesus alive again; all they could do was wait to be reunited with him in the Kingdom of God. There were no grounds leading them to hallucinate him alive from the dead. Moreover, the frequency and variety of circumstances belie the hallucination theory. Jesus was seen not once, but many times; not by one person, but by several; not only by individuals, but also by groups;

\footnotetext{
${ }^{28}$ John 19:32-34 New International Version.

${ }^{29}$ Warren W. Wiersbe, The Bible Exposition Commentary, Vol. 1 (Wheaton Illinois: Victor Books, 1989), 617.
} 
not at one locale and circumstance but at many; not by believers only, but by skeptics and unbelievers as well. The hallucination theory cannot be plausibly stretched to accommodate such diversity.

There are none of the previous counter-explanations can account for the evidence as plausibly as the resurrection itself. One might ask, "Well, then, how do skeptical scholars explain the facts of the resurrection appearances, the empty tomb, and the origin of the Christian faith?" The fact of the matter is, they don't. Modern scholarship recognizes no plausible explanatory alternative to the resurrection of Jesus. Those who refuse to accept the resurrection as a fact of history are simply self-confessedly left without an explanation. ${ }^{30}$

\section{The Mythical Theory}

Some critics charge that the Gospels have obscured the historical Jesus of Nazareth by cloaking Him in layers of legend and myth. They claim that the Bible's stories of Christ's resurrection are myth, not history.

The mythical view asserts that Jesus' resurrection was a myth created by the early church to maintain and grow the significance of Jesus' teaching and death. The major problem with this view is that Paul's testimony in 1 Corinthians 15:3 demonstrates that this so-called "myth" began early in the church.

If it began early in the church, and had no real basis in history whatsoever, it is difficult to see how it could have been propagated for any length of time. fails. ${ }^{31}$

There are at least four reasons why the mythological interpretation

First, comparative literature demonstrates that myth takes a number of generations to develop. There are no parallels in other literature of myth developing and being believed in the presence of eyewitnesses and within the short timeframe in which the New Testament was formed.

Second, many of these eyewitnesses to Christ's public ministry were hostile toward the Jesus the Gospels describe (Matthew 12:22f). These opponents had both motives and means to correct falsehoods about Him had the first disciples attempted them. Yet their opportunity did not produce a serious correction.

\footnotetext{
${ }^{30}$ William Lane Craig, Contemporary Scholarship and the Historical Evidence for the Resurrection of Jesus Christ, available from http:/www.leaderu.com/truth/ltruth22.html, cited on April $7^{\text {th }} 2009$.

${ }^{31}$ Some say that Christ's resurrection was a myth, not history. Is this possible? Available from http://www.christiananswers.net/q-eden/edn-t009.html, cited on April $8^{\text {th }} 2009$.
} 
Third, the Gospels don't resemble either Greek myth or Jewish legend. In contrast to those, the Gospels understate and lack embellishment, yet contain details counterproductive to the invention of legendary heroes.

Fourth, Jews were the poorest of candidates for inventing a mythical Christ. No other culture has so opposed mythically confusing deity with humanity, as did the Jewish.

If it began early in the church, and had no real basis in history whatsoever, it is difficult to see how it could have been propagated for any length of time. Let alone become the foundation of the church.

\section{CHAPTER IV THE EFFECT OF RESURRECTION}

According to the New Testament, Christ Jesus was born of a virgin, lived a sinless live, healed the sick, raised the dead and preached the good news. His enemies judged, arrested and crucified Jesus Christ, but they could not keep the Lord Jesus Christ in the grave. Three days later He rose again from the dead. Praise the Lord, because the resurrection of Christ affecting Christian faith.

\section{A. The Assurance of Salvation}

The resurrection of Christ guarantees the assurance of salvation and the eternal life in Christ. Archer, strongly mention that the bodily resurrection was God's certification to the world that the Savior of mankind had paid a valid and sufficient price for sinners and that He had for them overcome the curse of death. ${ }^{32}$ The resurrection indicated that the work of the cross was completed. The resurrection shows that God the Father accepted the sacrifice of Jesus Christ, His Son.

Christ resurrections give us hope in the future resurrection and certitude far greater than we previously had of life beyond the grave. Christ himself tells this saying "I am the resurrection and the life; he that believeth in me, although he be dead, shall live" (John 11:25). The apostle Peter also proclaims "God raised Him up from the dead, and gave Him glory, that your faith and hope might be in God" (1 Peter 1:21).

The resurrection shows that the Gospel is true. Because of the resurrection of Christ, we can have the gift of eternal life. That is one of the most important reasons for the death and resurrection of Jesus. No one could be saved and go to heaven without the resurrection of Jesus Christ from the dead. We are still in our sins if the resurrection did not

\footnotetext{
${ }^{32}$ Gleason L. Archer, Encyclopedia of Bible Difficulties (Grand Rapids, Michigan: Zondervan Publishing House, 1982), 235.
} 
happen. The resurrection is crucial to the salvation of sinners, because without the resurrection we are still lost in our sins. ${ }^{33}$

The salvation depends on faith in the resurrection of Jesus Christ. Bible says that if you confess with your mouth "Jesus is Lord" and believe in your heart that God raised him from the dead, you will be saved. ${ }^{34}$ This means that one's cannot be a Christian unless you believe in the resurrection of Jesus Christ. This should tell that even if some people are in churches, if they reject the resurrection of Jesus Christ, they are not Christians. ${ }^{35}$

The Justification was secured by his obedience to the death, and therefore he was raised from the dead. Paul wrote, "He was delivered over to death for our sins and was raised to life for our justification" (Rom. 4:25). His resurrection is a proof that he made a full atonement for our sins, that his sacrifice was accepted as a satisfaction to divine justice and his blood a ransom for sinners. It is also a pledge and an earnest of the resurrection of all believers (Rom. 8:11; 1 Cor. 6:14; 15:47-49; Phil. 3:21; 1 John 3:2).

Christ's resurrection is an earnest of the believer's resurrection. In this world sorrow is our lot, but in heaven there is joy, a fullness of joy; our pleasures here are for a moment, but those at God's right hand are pleasures for evermore. Through this thy beloved Son, and our dear Savior, thou wilt show us, O Lord, the path of life; thou wilt justify our souls now, and raise our bodies by thy power at the last day; when earthly sorrow shall end in heavenly joy, pain in everlasting happiness. ${ }^{36}$

Charles Spurgeon commented, "This is a noble encouragement to all the saints; die they must, but raise they shall, and though in their case they shall see corruption, yet they shall raise to everlasting life. Christ's resurrection is the cause, the earnest, the guarantee, and the emblem of the rising of all his people. ${ }^{37}$ As he lives, the believers shall live also.

\section{B. The Day of the Lord}

The Lord's Day is another effect of the resurrection. The disciples immediately began to meet together in commemoration of Jesus' resurrection. The Bible said, "On the evening of that first day of the week,

\footnotetext{
${ }^{33}$ Why Is The Resurrection Important? http://www.resurrection. azprophecy.com/ what-the-resurrection-means.php, cited on April 7th 2009

${ }^{34}$ Romans 10:9 New International Version

${ }^{35}$ P. G. Mathew, The Resurrection of Jesus Christ, available from http://dcn.davis.ca.us/_gvcc/radio_trans/resurrection.html, cited on April $8^{\text {th }} 2009$

${ }^{36}$ Matthew Henry, Matthew Henry's Commentary on the Whole Bible (Waynesboro, Georgia: OM Literature, 1995), 371.

${ }^{37}$ Alister McGrath and J.I. Packer, eds., The Crossway Classic Commentaries: Psalms vol. 1 (Wheaton, Illinois: Crossway Books, 1993), 47.
} 
when the disciples were together ... A week later His disciples were in the house again and Thomas with them (John 20: 19, 26). On the first day of the week we came together to break the bread (Acts 20:7)."

It is remarkable thing that the apostles who were Jews should turn from the observance of their time-honored Sabath Day, which had been given in Eden and been made a sign of their covenant relation with God (Exodus 31:13; Ezek. 20:12, 20), to Sunday worship. The origin of the Lord's Day can be accounted for only on the ground that the apostles change it in honor of Christ's physical resurrection and with his approval. ${ }^{38}$ The Jewish believers, meanwhile, were so impressed by this miracle that they began to worship on the day of Christ's resurrection, Sunday, rather than on Saturday, as their custom had been.

\section{Changed Lives of the Disciples}

Another evidence for the resurrection of Jesus is the changed lives of the disciples. The fact is that before the resurrection they were frightened men and were hiding away in fear of their lives. The disciples knew Christ had died and were skeptical at first concerning His resurrection, but when they saw Him alive, they were completely changed. After the resurrection, they preached everywhere for no earthly benefit, only suffering and martyrdom. There was a definite change in the disciples after the resurrection, especially noticeable in Peter. ${ }^{39}$

Look at the life of the Apostle Paul. What changed him from being a persecutor of the church into an apostle for the church? It was when the risen Christ appeared to him on the road to Damascus (Acts 9:1-6).

The early believers were beaten, stoned, thrown to the lions, tortured and crucified for sharing a lie, if the resurrection had not occurred. The ultimate martyrdom of thousands of believers is one of the strongest proofs of the resurrection of Jesus Christ. ${ }^{40}$ Because of the miracle of Christ's resurrection, Jesus' depressed and disappointed disciples were instantly transformed. They began to preach the gospel with power, and the resurrection of Jesus was at the heart of their preaching. These disciples of Jesus willingly suffered martyrdom for their faith. The enemies of the gospel were totally unable to refute this central

\footnotetext{
${ }^{38}$ Henry C. Thiessen, Lectures in Systematic Theology (Grand Rapids, Michigan:

William

B. Eerdmans Publishing Company, 1987), 247.

${ }^{39}$ Robert P. Lightner, Handbook of Evangelical Theology (Grand Rapids, Michigan: Kregel Publications, 1995), 89.

${ }^{40}$ Key Evidence for the Resurrection of Jesus Christ --Changed Lives of the Disciples, available from, http://www.resurrection.azprophecy.com/changed-lives-evidence.php, cited on April $7^{\text {th }} 2009$.
} 
claim of the gospel. They could not produce the body of Jesus Christ and put a stop to Christianity.

Among the twelve disciples, ten died for their belief in Christ's resurrection and their belief in Him as the Son of God. This is significant because if Jesus had not risen from the dead His disciples knew it. People may die for something they believe to be true, but is in fact false. But if the resurrection did not happen, the disciples did not just die for a lie that they mistakenly believed to be true, but died for a lie that they knew was a lie. Ten people would not all give their lives for something they knew to be a lie.

\section{The existence of the Christian Church}

The existence of the Church confirms the resurrection. If Christ had no resurrection body, then there is no mystical body performed by the Holy Spirit who came as the result of Christ resurrection and ascension. The fact and presence of the Church, then, demonstrates the proof of the resurrection and believer is a living proof of such a doctrine, Lockyer explained. ${ }^{41}$

Without belief in the resurrection of Jesus, Christianity could never have come into being. The crucifixion would have remained the final tragedy in the hapless life of Jesus. The origin of Christianity hinges on the belief of these earliest disciples that Jesus had raised from the dead. $^{42}$

The existence of the church is dependent on the fact of the resurrection. The early church grew through the preaching of the doctrine (Acts $2: 24-32 ; 3: 15 ; 4: 2$ ). ${ }^{43}$ Without the resurrection, there is no Christianity. Josh McDowell writes, "The Church was founded on the resurrection, and disproving it would have destroyed the whole Christian movement. However, instead of any such disproof, through the lst century, Christians were threatened, beaten, flogged and killed because of their faith. ${ }^{44}$

\section{E. The Completion of the New Testament}

The books of the New Testament itself are also an effect of the resurrection. There is no New Testament, if there is no resurrection.

\footnotetext{
${ }^{41}$ Herbert Lockyer, All the Doctrines of the Bible (Grand Rapids, Michigan: Zondervan Publishing House, 1974), 53.

${ }^{42}$ William Lane Craig, Contemporary Scholarship and the Historical Evidence for the Resurrection of Jesus Christ, available from http:/www.leaderu.com/truth/ltruth22.html, cited on April $7^{\text {th }} 2009$.

${ }^{43}$ Paul Enns, The Moody Handbook of Theology, (Chicago: Moody Press, 1989), 235.

${ }^{44}$ Evidence for The Resurrection of Christ, available from http://www.bellaonline.com/articles/ art9100.asp, cited on April. $7^{\text {th }} 2009$.
} 
Evans says, "If Jesus had remained buried in the grave, the story of His life and death would have remained buried with Him." ${ }^{45}$

If the resurrection of Christ were to be abandoned no Gospel or Epistle would remain in the New Testament. That Christ had risen from the dead by His own power was the message that the believers of the New Testament period were concerned to make known. They never for a moment imagined that there could be a Gospel apart from the resurrection. ${ }^{46}$

\section{CHAPTER V CONCLUSION}

Jesus is the resurrection and the life. He'll never wear grave clothes again. When he appeared to his disciples after the resurrection, he appeared not in a shroud of death, but walking in endless life. ${ }^{47}$

The Lord Jesus is the Son of God who became man. He is very God and very man. He was crucified, he died and was buried, and he was raised from the dead on the third day according to the Scriptures.

The proofs of resurrection can be found both in the Scripture and also in the history. Historically, the empty tomb and Jesus appearances to His disciples and many of His followers are clear proving that the resurrection of Chris is real. Biblically, it was the main preaching and teaching of the apostles. Beside that Jesus Himself prophesied and teaches about His resurrection.

These three great facts--the resurrection appearances, the empty tomb, and the origin of the Christian faith--all point unavoidably to one conclusion: The resurrection of Jesus. Today the rational man can hardly be blamed if he believes that on that first Easter morning a divine miracle occurred. ${ }^{48}$ Further fact is, if no resurrection, there will no church, there will no Christianity. Because of Jesus resurrection, the believers have assurance future life. Because He lives, there is hope for the future; there is certain hope for the salvation of the believers.

91.

${ }^{45}$ William Evans, The Great Doctrine of the Bible, (Chicago: Moody Press, 1949),

${ }^{46}$ Raymond Taouk, The Importance of the Resurrection, available from http://www.catholic apologetics.info/apologetics/islam/risen.htm, cited on Nov. $7^{\text {th }}$ 2007

${ }^{47}$ Why Is The Resurrection Important? Available from http://www.resurrection.azprophecy.com/ what-the-resurrection-means.php, cited on April 7th 2009.

${ }^{48}$ William Lane Craig, Contemporary Scholarship and the Historical Evidence for the Resurrection of Jesus Christ, available from http://www.leaderu.com/truth/ltruth22.html, cited on April $7^{\text {th }} 2009$. 
It can be said, there are no one theory can proof the rejection of the historicity of the resurrection of Christ.

How do we respond to the resurrection of Christ? "Believe in the Lord Jesus and you will be saved," Paul told the Philippian jailer (Acts $16: 31)$.

\section{BIBLIOGRAPHY}

Archer, Gleason L. Encyclopedia of Bible Difficulties. Grand Rapids, Michigan: Zondervan Publishing House, 1982.

Berkhof, Louis. Systematic Theology. Grand Rapids, Michigan: William B. Eerdmans Publishing Company, 2002.

Chafer, Lewis Sperry. Sytematic Theology, Volume one, Abridged Edition. Wheaton, Illinois: Victor Books, 1988.

Enns, Paul. The Moody Handbook of Theology. Chicago: Moody Press, 1989.

Evans, William. The Great Doctrine of the Bible. Chicago: Moody Press, 1949.

Henry, Matthew. Matthew Henry's Commentary on the Whole Bible (Waynesboro, Georgia: OM Literature, 1995.

Lightner, Robert P. Handbook of Evangelical Theology. Grand Rapids, Michigan: Kregel Publications, 1995.

McGrath, Alister and Packer, J.I., eds. The Crossway Classic Commentaries: Psalms vol. l. Wheaton, Illinois: Crossway Books, 1993.

Thiessen, Henry C. Lectures in Systematic Theology. Grand Rapids, Michigan: William B. Eerdmans Publishing Company, 1987.

Wiersbe, Warren W. The Bible Exposition Commentary, Vol. 1. Wheaton Illinois: Victor Books, 1989.

\section{Website}

Craig, William Lane.Contemporary Scholarship and the Historical Evidence for the Resurrection of Jesus Christ. Available from http://www.leaderu.com/ truth/ltruth22.html

Desiring God Staff. Historical Evidence for the Resurrection. Available from http://www.desiringgod.org/ResourceLibrary/Articles/ByDate/200 7/2390_Historical_Evidence_for_the_Resurrection/

Mathew, P. G. The Resurrection of Jesus Christ. Available from http://dcn.davis.ca.us/ -gvcc/ radio trans/resurrection.html

Evidence for The Resurrection of Christ, available from http://www.bellaonline.com/articles/ art9100.asp 
Evidence of the Resurrection. Available from http://www.resurrection.azprophecy.com/

Jensen, Gary W. and Taylor, Paul S. Is it possible that Jesus did not die, but only fainted on the cross, later recovering from His wounds? Available from http://www.christiananswers.net/q-eden/edn-t013.html

Key Evidence for the Resurrection of Jesus Christ --Changed Lives of the Disciples.

Available from, http://www.resurrection.azprophecy.com/changed-livesevidence.php

Lang, Christopher, Louis. Historical Evidence for the Resurrection of Christ. Available from

http://www.xenos.org/classes/papers/doubt.htm

McDowell, Josh. Evidence for the Resurrection. Available from,

http://www.bible.ca/d-resurrection- vidence-Josh-McDowell.htm

Some say that Christ's resurrection was a myth, not history. Is this possible? Available

from http://www.christiananswers.net/q-eden/edn-t009.html

Taouk, Raymond, The Importance of the Resurrection. Available from http://www.catholic apologetics.info/apologetics/islam/risen.htm

Ultimate Victory of the Resurrection. Available from

http://www.resurrection.azprophecy.com/ gospels-recordresurrection.php

Why Is The Resurrection Important?

http://www.resurrection.azprophecy.com/what-the-

resurrection-means.php 